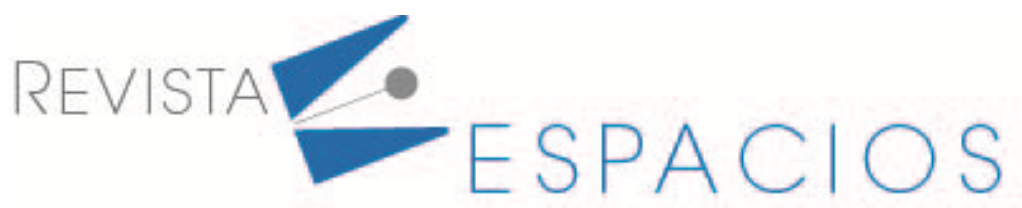

\title{
Medical tourism as a way to strengthen the Health Sector and its implications in the Regional Economy, Case Study: City of Bucaramanga and its Metropolitan Área, Colombia
}

\author{
El turismo médico como medio de fortalecelicimiento para el Sector Salud y sus \\ implicaciones en la Economía Regional, Caso de Estudio: Ciudad de Bucaramanga y su Área \\ Metropolitana, Colombia
}

MARIÑO, Juan P. ${ }^{1}$

PINOCHET, Giselle ${ }^{2}$

FLORES, Silvestre ${ }^{3}$

\begin{abstract}
The work compiles the findings of an investigation focused on the structure of the medical tourism value chain in Bucaramanga-Colombia, characterizing the relationships between the actors that make it up and explaining the dynamics of the health cluster in Santander. It is a cross-sectional study with explanatory scope within the qualitative paradigm, which raises the need to integrate tourism with the health cluster as a mechanism to position this destination internationally, improving the economy of the region.

key words: medical tourism, value chain, health cluster.

\section{Resumen}

El trabajo recopila los hallazgos de una investigación centrada en la estructura de la cadena de valor del turismo médico en Bucaramanga-Colombia, caracterizando las relaciones entre los actores que la integran y explicando la dinámica del clúster de salud en Santander. Se trata de un estudio transversal con alcance explicativo dentro del paradigma cualitativo, que plantea la necesidad de integrar el turismo con el clúster de salud como mecanismo para posicionar internacionalmente este destino, mejorando la economía de la región.

Palabras clave: turismo médico, cadena de valor, clúster de salud.
\end{abstract}

\section{Introducción}

The World Tourism Organization (UNWTO), says that tourism is recognized as a high impact activity worldwide, international and national, that focuses on promoting peace and prosperity in the regions, contributing to the

\footnotetext{
${ }^{1}$ Research professor at the Faculty of Economic and Administrative Sciences of the Antonio Nariño University, member of the research group Innovation, Competitiveness and Productivity of Organizations, recognized and categorized by Colciencias. Calle 58 A BIS \# 37 - 94 Telephone: (+57 1) 3152980. Email jupamarino@uan.edu.co

${ }^{2}$ Research professor at the Faculty of Economic and Administrative Sciences of the Antonio Nariño University, leader of the research group Innovation, Competitiveness and Productivity of Organizations, recognized and categorized by Colciencias. Calle 58 A BIS \# 37 - 94 Telephone: (+57 1) 3152980. Email gpinochet@uan.edu.co

${ }^{3}$ Research Professor. PhD in Tourism Management. Autonomous University of Occident. Email: silvestre.flores@uadeo.mx
} 
economic and social progress of developing countries (UNWTO 2014), being responsible for contributing $10 \%$ of the Gross Domestic Product (GDP) worldwide, creating 1 of every 10 jobs offered around of the orb (UNWTO 2018).

For its part, the National Federation of Merchants (FENALCO) and the Mayor's Office of Medellín (2018), assure that in Latin America, the countries with the highest contributions to GDP from travel and tourism in 2017, were Mexico with 7.1\%, Costa Rica with 5\%, Peru with 3.8\%, Argentina with 3.7\% and Colombia with 2.1\%, being a nation that still contributes below the neighboring countries and the Latin American average (3.1\%). In this regard, the Tourist Indicators System of Medellín Antioquia (SITUR), establishes that, for Colombia, the direct contribution of travel and tourism to GDP in 2017 was 19,662.6 billion Colombian pesos, equivalent to $2.1 \%$ of the national GDP, figure that when including foreign investment, marginal income by value chain, and externalities, reached $53,473.6$ billion, corresponding to $5.8 \%$ of the total GDP (FENALCO 2018).

The Ministry of Commerce, Industry and Tourism (MinCIT 2018), states that Colombia is the Latin American country with the most dynamism in tourism development and one of the most outstanding in the world, due to the increasing number of travelers' arrivals in recent years. In this regard, the National Planning Department (DNP 2019), citing the Special Administrative Unit for Migration Colombia (2019), points out that, in 2015, tourism attracted 1,598,722 foreign visitors, a figure that increased to $1 \%$. 871,365 in 2016, maintaining an increase in 2017 until reaching 2'521.900, reaching a record figure of 3'270,356, of tourists in 2018.

The DNP (2019) adds, that to be competitive, Colombia needs to develop its productive potential, reducing its dependence on the export of hydrocarbons, and instead, strengthening sectors such as tourism, which has all the potential to become what has been called the "new oil". The DNP specifies that, to maintain the constant growth of the last years, the tourist activity will develop its tourist offer focusing on products of nature, ecotourism, agritourism, adventure and science, sun and beach, cruises, culture, gastronomy, heritage, music and religion, investment, business and entrepreneurship, tourism meetings, conventions, corporate and social events, and finally, the inclusive tourism of health and well-being.

For its part, the Chamber of Commerce of Bucaramanga (CCB 2019), through the Tourism Information System of Santander, states that the tourism activity in this Department contributes $4.9 \%$ of the departmental GDP, involving more than 1570 companies formalized before the National Registry of Tourism as providers of adventure tourism services, cultural and business tourism. However, the results of this 2018 regional analysis, does not refer to the potential of the Department to develop medical tourism.

According to the CCB (2017a), the Department of Santander is the third region with the highest number of medical and dental care centers per capita in Colombia, six of which are among the 100 largest in the country, generating the second income per capita in health among the main regions of the country. Santander has 24 companies in route, with cumulative sales of over one trillion pesos at the end of 2016, 86 new micro companies (with less than 50 million pesos in assets), SMEs and large companies directly related to the health sector in the last 2 years, and 831 micro companies (with less than 50 million pesos in assets), SMEs and large companies, chained to health businesses.

Additionally, between 2008 and 2016, Santander ranked fourth in annual average growth of its GDP in health, considering the 5 main economies of the country (Departments of Atlántico, Santander, Antioquia, Valle and the District of Bogota), which represented a contribution of $4.5 \%$ to the GDP of National Health, and of $1.5 \%$ to the GDP of the Department, achieving between 2008 and 2016, an increase of 11 percentage points in the participation of the health GDP within the departmental GDP, and a contribution of $6 \%$ of the health input, to the services sector in Santander. 


\subsection{Importance of the study}

Medical tourism is a millenary practice, because in all periods of history people have traveled in search of thermal waters, milk, and even male fluids (semen), for therapeutic baths as well as medicinal plants, in order to mitigate or cure rheumatological, dermatological, respiratory and renal diseases (Rodríguez ,1998; Rey, 2008; Branco et al., 2011; Arias et al., 2012).

For Minseong et al., (2017), there is a dialectic around medical tourism that is a product of its close relationship with health tourism, since for some authors, both denominations are focused on the same purpose involving the entire range of medical services and even welfare. On the particular Quintela et al., (2016) consider that welfare and medical tourism, are integrated within the general context of health tourism, as underlies a permanent relationship of treatment against the disease, through preventive procedures, curative and palliative.

On the contrary, Arias et al., (2012) and De la Puente (2015), affirm that the main trunk is the medical tourism and from it, the tourism of health (vital processes) and the tourism of welfare, understood as aesthetic procedures or activities focused on the care and improvement of the body. Likewise, the aforementioned authors agree that none of the above categories includes outsourced services, that is, those health services that tourists receive while they remain in a country when their trip is not motivated to acquire said benefits.

On the other hand Mendoza (2014), considers that the medical tourism refers to all the surgical, pharmacological, ambulatory procedures (dental, ophthalmological and / or cosmetics among many), which are realized as mechanisms for the treatment of the diseases, of the which, various classifications are established according to the pathologies, the time of stay and recovery of the patient, their place of residence and the choice of destination that they do, based on their level of technological advancement, for the performance of surgical procedures, complex treatments, plastic surgeries and level of specialists (Fuentes 2009).

Likewise, Turner (2011), includes alternative medicine within medical tourism, as a specific category, which combined with the different modalities of traditional medicine allow to obtain satisfactory results. For the aforementioned author, medical tourism not only deals with obtaining a vital or aesthetic service, but also includes patient safety, marketing, offering medicines as agents for the treatment of a disease and even the procurement of organs for transplants, that allow to save or guarantee a better quality of life for the patient.

As for its dynamics, Adams et al., (2013), affirm that medical tourism has expanded worldwide, since it demands that patients travel outside the country of residence in order to obtain paid medical care, due to the lack of coverage of the health sector of some countries, under penalty of poor quality procedures and low regulation standards. However, Turner (2011), ensures that, although medical tourism arises when a trip is made, it can be inside or outside the borders of the country in which the patient lives, for the purpose of undergoing medical treatments that may include the practice of vital or aesthetic procedures according to the client's needs.

Faced with its economic relevance, Castro (2007), explains the rapid growth of medical tourism worldwide, due to the rising costs of medical care in developed countries, cross-border medical training and the cost of air transport, which is why, most governments of developing countries see medical tourism as an opportunity to generate more income, therefore, they are adapting their legislations and hospital medical structures to implement it (Heung et al., 2011). Specifically, Asia is the continent that leads the list of countries that have focused on the implementation of medical tourism, in destinations such as India, Singapore and Thailand (NaRanong and NaRanong 2011).

It is worth considering that touristic destinations find their vocation based on the structures, infrastructures and super structures they have and on the profile of tourists and the reason encouraging them to make a certain trip. With this in mind, Adams et al., (2013), highlight the economic effort made by some low-and middle-income 
countries, to capture the attention of medical tourists, improving their perception. However, the medicine industry is currently segmented by markets in which patients, being consumers, become the agents responsible for their health. This means, patients are directly responsible for the use of treatments as a cure or prevention of a disease, as well as for effectively saving on the costs of such treatments, as part of traditional tourism purposes.

\subsection{Impact on public policies, programs and projects in the tourism activity, regional economy, and social area}

According to the mentioned authors, developing countries should focus on the medical care of foreign patients in order to offer them a better health service by increasing their economic income and the worldwide recognition of public and private entities of the national order. Similarly, by generating this focus on foreign services, the training of highly trained workers is encouraged, which will strengthen the medical sector of the entity that implements it, offering at the same time a better service for all its patients.

Minseong et al., (2017) coincide, noting that medical tourism is the typology with the greatest economic potential as travelers invest in airlines, accommodation, medical care and gastronomy in a foreign country, radiating an economic spill over the entire chain. In this regard, De la Puente (2015), states that this phenomenon constitutes a challenge for those nations focused on attracting foreign patients and insurers, interested in more affordable procedures, since the displacement of patients and their helpers consolidates a tourism opportunity derived from the treatment of the affections of the ill. In addition to avoiding the deterioration of their income because of the high on-site costs, these clients secure the space to experience conventional tourism, taking advantage of their recovery at the treatment site. In the words of Anido (2012), medical tourism benefits patients with quality medical interventions, offering them the opportunity to learn about the attractions of host countries.

This is an opportunity that the National Planning Department (DNP by its acronym in Spanish 2015) recognizes in the National Development Plan (DNP 2014-2018), by stating that in Colombia the provision of health services must be prioritized in virtue of the great demand that this sector demonstrates worldwide.

Despite this, De la Puente (2018) ensures that medical tourism in Colombia is an incipient industry, which offers opportunities for cities whose actors demonstrate adaptability and an international level of quality in the provision of services. It adds that the United States is the largest issuer of patients, corroborating the annotation of the Economic Commission for Latin America and the Caribbean (CEPAL by its acronym in Spanish 2010), when it ensures that patients from industrialized countries travel to developing countries in search of procedures. Doctors at lower costs compared with those of their countries of origin, therefore, medical tourism is a very lucrative activity for developing countries (Heung et al., 2011).

The high costs of health systems in the Caribbean are a capitalized opportunity for the city of Bucaramanga and the towns around its metropolitan area for tourist-patient care. According to the Center for Touristic Thought (CPTUR 2017), 25,903 foreign tourists visited the Department of Santander in 2017. In this regard, the Chamber of Commerce of Santander (CCB 2017a), ensures that this region has developed an economy based on health services, generating notorious economic growth, as a result of the consolidation of a productive chain composed of about 4,385 companies among providers, insurers and care centers focused on various specialties according to the needs of patients.

According to CCB (2017a), this peak led to the emergence of new specialties and undergraduate and graduate programs, which have graduated about 7,252 professionals between 2012 and 2015, a figure that reflects the level of qualified, diversified and internationally recognized offer. In sum, Bucaramanga and its metropolitan area committed to medical tourism, seeking to position the Department of Santander as a specialized destination in 
the care of highly complex procedures, focused on the export of medical services based on the structuring of two medical free zones.

Based on this business dynamic that welcomes more than 4,000 business units in the Santander health sector, in 2015 the Santander Health Cluster (SHC) initiative emerged as a mechanism to strengthen the competitiveness of the sector, linking more than 36 companies dedicated to manufacturing, distribution, commercialization and providing medical services in different areas (CCB 2017b), whose actions have focused on articulation projects and activities that seek specialization in specific products and services, medical differentiation and generation of new knowledge based on innovation and support from transversal actors integrated to the Cluster, such as universities, health secretariats and other institutions whose contributions, according to the union, reach more than $\$ 2,250,000,000$.

\section{Materials and methods}

This article collects the findings of a research focused on explaining the structure of the value chain of medical tourism, in the city of Bucaramanga and its metropolitan area, characterizing the relationships between the different actors that make it up, and explaining the dynamics that show and/or blur the operation of a health cluster in the Department of Santander, based on the governance that is consolidated from the companies that constitute it.

In this sense, the developed research emerges as a cross-sectional study that embraces the qualitative paradigm, compromising an explanatory scope as a methodological strategy. In addendum, given the particularities of the context and the detected problem situation, the "case study" is consolidated as the most relevant research design to analyze a phenomenon whose dynamics are unique in Colombia, given that, Bucaramanga has two medical free zones and an industrial company within the value chain of its health sector, where the Ophthalmological Foundation of Santander (FOSCAL) and the Cardiovascular Foundation of Colombia stand out as health providers, characterized by exercising strong governance over the other actors in the health sector chain, being, in turn, platforms of the Health Cluster. Regarding the tools used to obtain the data, the present investigation turned to documentary review, development of semi-structured interviews, and audio-visual records that support the inquiries that were made with the informants (See table 1).

Table 1

Informers

\begin{tabular}{|c|c|c|}
\hline Interest Group & Linked Institutions & Informer's Position \\
\hline \multirow{4}{*}{ Health Care Institutions (Ips) } & $\begin{array}{l}\text { Comprehensive ophthalmological clinic of } \\
\text { Bucaramanga COI }\end{array}$ & General Manager \\
\hline & \multirow{2}{*}{$\begin{array}{l}\text { International Hospital of Colombia FREE ZONE, } \\
\text { Piedecuesta } \\
\text { Cardiovascular Foundation of Colombia }\end{array}$} & Head of International Services \\
\hline & & Audit of the Cancer Institute \\
\hline & $\begin{array}{l}\text { Ophthalmological Foundation of Santander (FOSCAL) } \\
\text { FREE ZONE, Floridablanca }\end{array}$ & Head of International Services \\
\hline Aesthetic Medicine Service Provider & Skin clinic and reconstructive surgery & General Manager \\
\hline Welfare Service Provider & Sindamanoy Welfare Center & Director \\
\hline \multirow{2}{*}{ Associations } & Chamber of Commerce of Bucaramanga & Executive of tourism projects \\
\hline & Health Cluster of Bucaramanga & Director \\
\hline Municipal Government Institutions & Mayor's office of Floridablanca & Secretary of tourism \\
\hline Consulting Companies & Productive transformation program & Director \\
\hline $\begin{array}{l}\text { Tour Operators Specialized In The } \\
\text { Export Of Medical Services }\end{array}$ & $\begin{array}{l}\text { International Center for Management of Medical and } \\
\text { Tourist Services }\end{array}$ & General Manager \\
\hline
\end{tabular}

Source: Author's elaboration (2018) 


\section{Results}

Bucaramanga and its metropolitan area have been transformed due to the economic development achieved from the growth of the sector services, which has traditionally characterized the region's economy. Despite this evolution, traditional sociocultural practices are maintained, which warn of the rural nature of the work of the productive actors immersed in it, which contrasts with the new profile of the city, in an alchemy that shows progress, without sacrificing the quality of life of its inhabitants. According to studies of CCB (2017a), Bucaramanga is placed as the third region with the highest number of medical and dental care centers per capita within the country.

Bucaramanga has multiple comparative advantages, since it is located in an equidistant point between the Caribbean coast, the capital of the republic, the border with Venezuela and very close to the Barrancabermeja oil area, making the development of a tourist activity different from the traditional destinations such as the Atlantic coast or the coffee axis, who have reached their maximum potential and are in the stage of maturity.

Referring to its competitive advantages, Bucaramanga and its metropolitan area have an international airport, night flights and direct connections from some countries, as well as roads and highways that connect them with the whole country, including fourth generation (4G) roads, such as the built between this city and the Caribbean coast.

Regarding the tourist inventory of the region, the department of Santander possesses all the thermal floors and landscapes that go from the rugged topography of red and warm soils of the Chicamocha canyon, where one of the main thematic parks of the country is located, to moors like the Santurbán moor, highlighted by its auric and aquifer potential, from which the supply of half of the water in the metropolitan area of Bucaramanga is achieved; the reservoir Hidrosogamoso, and the natural park El Rasgón, located in the municipality of Floridablanca.

This park has between 8,000 and 10,000 hectares of virgin mountain forest, whose biodiversity constitutes an enormous potential for ecotourism and agritourism, since more than 70 species of birds have been detected between national and migratory birds, many of them endemic. 19 different types of bats, and a unique frog in the world, discovered by Professor John Lynch, who baptized it under the name of "prestimantis jorgevelosae", in honor of the renowned singer-songwriter Jorge Velosa, who at that time was participating in the Carranguera music festival, genre musical that according to the scientist, is as typical of the region, as the frog in question, for what he found justifiable to give this name to the amphibian and make it the symbol of the park.

Additionally, within the metropolitan area of Bucaramanga is the Parapenting National Park, with one of the best scenarios in the country for the practice of this discipline, which together with El Rasgón Park and the Santísimo Hill, establish a set of attractions within the municipality of Floridablanca, which are consolidated thanks to the existence of specialized inns in the accommodation of tourists interested in landscaping, bird watching and nature tourism in general, within a scenario in which the medical free zones are inserted, which have become the most promising tourism product for the region.

Currently, Bucaramanga and the municipalities that make up its metropolitan area have positioned themselves as one of the most representative destinations for medical tourism in Colombia, thanks to the boom that has existed in the export of this type of service. Regarding the creation and evolution of the medical free zones, since 2006, a collegiate entity comprising the Government of Santander, the Mayor's office of Bucaramanga, businessmen, unions, academics, and local development agencies, has been meeting to lead an initiative that seeks to make Santander a competitive Department, based on the structuring of strategic projects focused on 10 pillars within which health services were included. 
Then, Inspired by the "Productive Transformation Program", the Regional Competitiveness Commission decides to take advantage of the existence of the Santander Free Goods and Services Zone; the Cardiovascular Foundation Free Zone of Colombia (International Hospital of Colombia HIC), and the Permanent Special Free Zone FOSUNAB Foundation (FOSCAL Clinic), to export all the medical potential of the region.

The first free zone arises from the Ophthalmological Foundation of Santander (FOS), which, after receiving a donation from the businessman Carlos Ardila Lülle, built a medical center in Floridablanca that bears his name, the Carlos Ardila Lülle Ophthalmological Foundation of Santander (FOSCAL). And a few blocks away, in the same municipality, in 2016 the FOSUNAB or the International Foundation Permanent Special Free Zone was established, whose name obeys the agreement initially signed between the FOS and the Autonomous University of Bucaramanga (UNAB), where basically, all doctors and nurses who graduated from that alma mater, did their internships at the FOSCAL International clinic.

Subsequently, the FOSCAL clinic decided to provide the services of cardiology and cardiovascular surgery, which, given the high demand, collapsed due to insufficient plant capacity, making it necessary to migrate to another building specialized in this type of procedure. It is then, when the Cardiovascular Foundation of Colombia was born, and with it, the initiative of the International Hospital of Colombia (HIC), a project that took place ten years later in the municipality of Piedecuesta, giving rise in 2017 to the Free Zone Cardiovascular Foundation of Colombia.

Both health institutions welcomed the free regime benefits from the 2147 decree of 2017, which offers tax exemptions as an incentive for investment and job creation, and were established to serve both national and international patients, defending a social purpose that transcends borders and seeks to impact Latin American level given the lack of institutions providing quality health services in Latin America. For this reason, the HIC seeks to become the best social project in Latin America, within a work plan projected to 25 years, which includes the construction in another country of a hospital with the same characteristics as in Colombia (See table 2).

Table 2

MEGA International Hospital of Colombia

Consolidating the greatest social project in Latin America and building a one billion dollars business corporation by 2025.

- To consolidate the International Hospital of Colombia (HIC) within the top 3 in Latin America and to bring its total billing to US\$350.000.000.000.

- To develop a network of "near, efficient and comprehensive" regional access nodes with revenues of more than US $\$ 200.000 .000 .000$.

- To offer specialized products and supplies for health service providers focused on value for US $\$$ 50.000 .000 .000 .

Source: Cardiovascular Foundation (2017)

The empirical evidence shows that this purpose is consistent with the data offered by the informants, since there are records of arrival of patients from Ecuador, Peru, the insular Caribbean, Panama, Mexico, and even from Brazil itself, where the Albert Einstein Hospital is located and considered the best hospital in Latin America. However, research carried out warns that despite being two health institutions internationally recognized for their quality and level, both FOSCAL and HIC barely reach an occupation of approximately $30 \%$ of their installed plant capacity, mainly providing their services to National Health Promoting Companies (EPS).

In this regard, the sources consulted coincide in pointing out that Bucaramanga really is not a sufficiently wellknown international destination, and that despite having advances in terms of air connectivity, for many interested patients living abroad it is preferable to arrive to cities such as Bogotá, Cali, Medellín or Barranquilla, 
which besides having greater tradition and recognition in carrying out medical procedures, have international airports that allow them to arrive directly.

On the other hand, the two free zones are relatively young since they came into operation in 2016 and 2017, which is why the lack of engagement with the other actors in the medical tourism chain is evident, especially with those that promote the vocation of the destination, as that specialized in the provision of medical services both internationally and nationally. Likewise, despite the fact that the two institutions are referents at Latin American level, it is essential to strengthen the image of the city as a space equipped with structures, infrastructures and superstructures, not only for the provision of medical services, but also for the recovery of patients within said territory, so issues such as accessibility and structural and architectural facilities, are made of priority intervention in health and tourism alchemy. This would significantly improve the competitiveness of the Department of Santander, since from these two free zones materialized what was proposed not only by the Bucaramanga Chamber of Commerce, but by several entrepreneurs related to the health sector, who had made multiple attempts for constituting the so-called Health Cluster.

In this sense, the consolidation of the Health Cluster, also recent, will make it easier to market the services that are provided because if the different links in the chain focus on linking within the free zones, they will be obliged to develop this type of structures and infrastructures and to have ready said constructions to be able to accede to the frank regime. This would fortify the emphasis of the destiny in medical subjects, and with it, an increase of the arrival of tourists with such intentions. It is worth mentioning that the conformation of the Santander Health Cluster has been a tedious process given the existing distrust among its members. Its evolution has allowed generating a dynamic around the activities of the provision of medical services where several companies converge, including, IPS, diagnostic imaging services and manufacture of biomedical products, among many, which in some cases are located within the Santander Free Goods and Services Zone.

To talk about its operation, it is imperative to make clear that the Health Cluster of Santander is leveraged in the Department's three free zones, since it must be remembered that in addition to the two medical free zones mentioned above, Santander has a third free zone of goods and services, which is multi-enterprise. It allows any company that wants to benefit from the free regime in terms of exemption from tariffs, customs costs and tax exemption.

Unlike this, the two free health zones are special health permanent free zones, which make it restrictive unienterprise. They are focused solely on their social purpose, which for this case, is the provision of medical services. Therefore, they could not develop other types of activities such as the importation of osteosynthesis material, although this is used within the surgical procedures that are regularly developed. In short, they can not carry out foreign trade operations covered under the free regime. In light of the operation of the Cluster, the existence of the multi-employer free zone becomes relevant as it complements the work of the medical free zones allowing the importation of medicines and supplies through the transit mechanism between free zones, which allows the transfer of medical products or drugs to the special free zones of health.

However, the findings show that the idea of the Santander Cluster is imprecise, as it is possible to identify the presence of holdings within the large medical service providers referred to as emblematic of the medical free zones. This is the case of the Cardiovascular Foundation of Colombia (HIC), which, as a result of the diversification of its strategic business units, has developed its own tissue bank and its own factory for sterilized hospital products, in response to the standards of Joint Commission International (JCl), which is intended to prevent the purchase of surgical clothing suppliers who do not work with standards of sterilization, so they even preferred to do it themselves, for which they created a department of metrology and sterilization. 
The interviewed sources assure that these strategic business units arise as a commitment to total quality, with a view to offering the best conditions to patients, without abandoning their main activity, which is the provision of medical services. However, at this point the dynamics of the cluster enter a gray zone, because it is not a marketing process where other economic entities fulfill their function of supplying inputs to other links within a chain, but basically, the provider assumes the functions of supplier, what can be considered a reverse horizontal integration.

This explains why the Cluster is not fully constituted and demonstrates there is still a long way to go so other links in the chain can profit from these diversifications, based on the establishment of the role and the disposition of the Cluster members and on the resources and capacities of each link. A space where the institutions that are part of the health sector can identify, associate, complement and in sum, develop a model of cooperation in equal conditions where they can propose projects and raise strategies for the benefit of the Cluster and the region, strengthening the delivery of medical services.

Regarding medical tourism, the entities belonging to the health sector work in order to offer conditions to attract a specific market and to meet their own health needs so they can develop a conventional tourism activity, but still, there is no articulator or generator of synergies that link them. There are internationally and nationally accredited IPS located in Bucaramanga with experience in the export of medical services and there are also companies that develop biomedical products for implants, which are in high demand in Colombia and throughout Latin America. There are doctors specializing in aesthetic medicine, alternative medicine centers, laboratories, diagnostic imaging centers, pharmacies, hotels, restaurants, spas, wellness centers and in general, companies dedicated to traditional tourism activities, but they all, working in isolation.

In this regard, both the HIC and the FOSCAL International, are integrating within their portfolios of service, specialties of less complexity in order to encourage medical tourism. For example, the Cardiovascular Foundation of Colombia has been developing the "Seniors House" project, consisting of accommodation located very close to the HIC, to which foreign retired clients arrive to practice the examinations and procedures they require. Likewise, with the support of PROCOLOMBIA and the Mayor's Office of Bucaramanga, the Cardiovascular Foundation of Colombia developed an international business round which allowed the signing of contracts for the provision of medical services with international insurers.

In addition, joining PROCOLOMBIA, the Cardiovascular Foundation of Colombia arranged commercial agendas in several countries, and together with the Chamber of Commerce of Bucaramanga, developed several referral visits to leading organizations in Latin America such as the Albert Einstein Hospital in Brazil, from which the strategic plan for the institution was generated, signing agreements that have represented the arrival in Bucaramanga of a significant number of visitors despite lacking the advantage of direct flights from other countries, as opposed to the cities of Bogotá, Medellín, Cali or Barranquilla. However, an important number of patients whose pathologies demand procedures of medium and high complexity, and therefore, of high cost, is being sent from Aruba. Each patient is generating a significant flow of foreign currency compensating in part the lack of volume, although definitely, the number of foreign patients is not enough to occupy the hospital structures available in these two free zones.

There are also other initiatives related to physical and psychiatric rehabilitation centers, such as the San Pablo Psychiatric Hospital, which based on a preventive medicine approach, has been working to mitigate mental illness through early intervention in psychiatric pathologies. But despite their importance, they are still isolated initiatives without enough impact to the progress of the medical subject in Bucaramanga.

Regarding the medical tourism market, Colombia holds a competitive advantage in terms of costs, because the procedures are around 30\% cheaper than in countries like the United States, being a definitive element when 
choosing, given its geographical proximity and cultural affinity, unlike other more distant suppliers in both aspects, such as India, Thailand and Malaysia. For this reason, for health systems such as those of the United States and Canada, medical costs in Colombia are highly attractive, since they allow the development of policies such as Obama Care, a measure with extended coverage promoting the entry of more patients to the U.S system that could not have been treated before.

By law, companies in these countries must include their employees in welfare programs and medical treatments in general, so they seek to save costs by sending them to countries such as Colombia, Costa Rica, Ecuador, Mexico or Panama, which currently are developing hospital citadels and receiving enough patients. Then, the cost itself is a decisive issue, to the point that most international insurers allow patients to choose the country where they want to be treated, being able to decide between the United States where they must assume a copayment, or a country like Colombia, Costa Rica, Ecuador, Mexico or Panama, with $100 \%$ of the cost covered, and additional tickets, hotel and extra money to travel, allowing a remnant to make tourism.

Regarding the main difficulties faced by the development of medical tourism in Bucaramanga, there is evidence of a lack of vision regarding the potential of this hybrid activity, particularly for a part of the actors of the health sector. In this regard, the findings show ignorance about the genesis of the concept in those who speak of medical tourism in the region, and consequently in the way of marketing these services, making them tangible to market.

It can be affirmed that, in spite of the efforts made by the providers of medical services in Bucaramanga, in particular, of the institutions of the free zones, it is necessary to integrate the tourist topic, because it is not enough to only promote quality services in the treatments and procedures of low, medium and high complexity. When analyzing the value chain of medical tourism in Bucaramanga, there are interruptions in the way its links are integrated, particularly with regard to the complementarity of tourist structures with medical services.

Specifically, there is the case of patients who must stay in hotels located in the urban area of the city being distant from medical complexes, having to assume the limitations that the city shows at the infrastructure level. Bucaramanga lacks roads that ensure a smooth travel and suffers from not being an inclusive city because it was not designed for the needs and access of clients with permanent or temporary disability, or with mobility in wheelchair or with walking aids, not to mention the hearing and visually impaired.

Another case is the specialized food diets, since the local gastronomic offer does not consider the demand of people with specific pathologies that require an appropriate food, as is the case of diabetic patients or those who need to follow a strict diet on a permanent or temporary basis. In this order of ideas, while patients are inside the health care institutions, their prescriptions and nutritional care are guaranteed but once they leave the medical centers and must continue their stay in the city to comply with the programmed controls, their dietary allowance might be unknown, as they do not find specialized restaurants.

Likewise, the issue of air connectivity is perhaps one of the most complex because it is not only the lack of airport infrastructure, but the lack of demand. A few years ago, Bucaramanga had a direct flight to Miami, but it was ended because of irregular flow of travelers and fewer patients waiting for medical attention, no more than five international patients. However recently the city mainly hosts patients from Curacao, Bonaire, San Martin, Trinidad and Tobago, Ecuador and Peru. There are only direct flights coming from Aruba and Panama where many patient-clients connect in three weekly frequencies. These flights operate an inadequate schedule for client transfer because it is arriving in Bucaramanga at around 11 p.m. and because it was conceived mainly for business travelers who want to stop for shopping in Panama and return the same day.

For a traveler with particular medical conditions, disembarking at midnight at an airport distant from their place of accommodation is difficult, and it makes evident the need to consider daytime schedules that facilitate a more comfortable arrival for this type of patients with routines and more common practices. However, there are 
airlines specializing in charter flights that can easily go to Miami and other destinations at a reasonable price, but the challenge is to fill the plane guaranteeing at least 15 patients with their respective helpers or companions, and be able to take them to Bucaramanga, making it a profitable scenario.

It is at this point that the facilitators of medical tourism underlie as entities capable of mitigating the asynchronies previously exposed, since medical tourists like to buy "packages" that cover all their needs. This is the case of patients whose pathologies demand low complexity procedures, such as laboratory tests, diagnostic imaging or many other non-invasive procedures that do not require hospitalization. For this segment of the market, especially if it is foreign, it is essential to have your accommodation, food and transportation covered. Thanks to their not critical health status they are included in traditional tourism activities such as city tours, shopping trips, visits to museums and iconic sites, while complying with the scheduled medical agenda, which includes appointments with the specialist, treatment, post-operative rehabilitation and in general, activities that demand closeness to medical institutions for short periods.

Although they live up to their name, the role of these facilitators has been questioned from the Health Cluster of Medellín, which for several years faced multiple crises derived from misgivings among its members, who beyond diverging by competition or rivalry, rejected these new links in the chain. They did not recognize new links as part of the Cluster and considered that they did not serve as promoters of its integral interests because they favored only some of its members as allies. For this reason, and given the time that Santander's health cluster has taken to work (around three years), what happened during the development of its Medellín pair, is predictable and may be expected in Bucaramanga.

Finally, regarding the tourism issue per se, one of the most common complaints among tourists visiting Bucaramanga for medical purposes is that, despite having been treated, they did not have the opportunity to experience the city, as the most of their stay was in the hospital. During the free time they had, they could not even visit a shopping center, given the complexity of the trips for the patient and his/her companion. When it comes to recovering, the destination is complicated by the unfriendliness of the city because for patients with pathologies or procedures that restrict their mobility, Bucaramanga is very demanding. They simply resign themselves to accept that when it comes to moving everything is difficult.

In short, most of the time, medical tourists must return to their places of origin without really knowing what the city is, establishing a turning point in which the concept of medical tourism is distorted, as only the provision of the health service, but the development of a tourist activity, is limited to the simple fact of staying overnight outside the usual place of residence. Therefore, the challenge Bucaramanga must assume is to promote itself to insurers, patients and companions, as a city friendly with its pathologies and limitations, endowed with the structures, infrastructures and superstructures necessary to make their stay in the city, a pleasant experience, not only from the medical point of view, but also, for the alternatives and quality of the tourist services that any patient may require.

Therefore, it is imperative to work on synergies to ensure these conditions, synchronizing all actors in the chain, aligning all providers of tourism services and doctors based on what patients need under the consideration that a traveling patient is totally different from any other type of tourist, since their activities are limited by their sufferings and it will be the ability of the city to adapt to the demands of the medical tourists, which will make Bucaramanga a competitive destination based on the premise of inclusive tourism.

The above corroborates the point made by Heung et al. (2011), when they assure that, a good tourism planning leads to the development of the region. So, if for Bucaramanga and its metropolitan area it is clear that medical tourism is the axis around which their tourism activity will be developed, then the region must plan adequately in search of it, starting from an exercise of classification of the type of tourists that visit it, based on the 
pathologies, and general medical needs considered in the offer, without forgetting that there are particular behaviors and characteristics that do not always correspond to people who require to undergo reactive but proactive procedures. In this order of ideas, it is necessary to establish a business prototype designed from the creation of value and satisfaction of expectations for national and international market segments, which demand both curative and preventive, aesthetic and wellness medicine.

\section{Conclusions}

Bucaramanga and its area of influence have achieved international recognition based on the international management carried out by the FOSCAL Clinic and the International Hospital of Colombia, which have focused on promoting mainly cardiology, ophthalmology, oncology, and tropical and chronic diseases treatment.

The marketing of Bucaramanga as a tourist destination, has been leveraged in the international diffusion of the quality of hospital medical services that the city has, consolidating a competitive advantage based on another comparison that lies in the tax benefits granted by its two medical frank zones and the industrial free zone.

Despite the international focus that is intended to provide medical services in Bucaramanga and its metropolitan area, it is the Colombian Healthcare Providers (local insurers), which refer the bulk of the hospital population served within the two free medical zones, whose hospital entities are highly aware of the inefficiency of the Colombian health system, especially in regard to the delay in payment of medical services provided to patients referred.

Bucaramanga and its metropolitan area have two completely independent value chains, the value chain of tourism and the value chain of the health sector which until now, are kept separate and do not have meeting points to identify an alchemy between these two activities.

The value chain of medical tourism in Bucaramanga and its metropolitan area is nonexistent, basically because it suffers from a real, direct, recognized, established and neat symbiosis between the links dedicated to the provision of medical and tourist services, making it necessary to articulate these productive units, to establish synergies in order to develop a true integral tourist product, around medical tourism.

To comply with international standards that allow it to be considered as a world-class medical tourism destination, Bucaramanga needs to guarantee the constitution of a functional value chain for medical tourism supported not only by the recognition of its medical expertise but also by the development of an inclusive city whose structures, infrastructures and superstructures grant guarantees to medical tourists who visit it.

The lack of air connectivity is not the cause of the low influx of international medical tourists to the region, but a consequence that derives from the low demand. To the extent that the number of international patients increases, the appearance of new destinations, and higher air frequencies will be the result to expect.

Medical tourism in Bucaramanga and its area of influence are focused on the care of patients who demand curative medicine but ignores three lines of business of equal or greater importance such as preventive, wellness and aesthetic medicine.

Given the limitations of infrastructure and superstructure that afflict Bucaramanga and its metropolitan area, preventive medicine and wellness activities offer the best prospects for the development of medical tourism, since they allow their patients to integrate more easily into the orthodox tourism activity, since their state of health is not as compromised, as in the case of those who go to health institutions in search of highly complex procedures. 
Those who practice aesthetic medicine in Bucaramanga and its metropolitan area, are considered an alien to the Health Cluster of Santander. They are recognized as a separate service, which attracts patients on their own merits thanks to the specialists' good will, whose procedures are far from those that can be marketed with insurers seeking benefit from economies of scale and from the standardization of procedures such as those carried out in the two medical free zones.

Santander's Health Cluster is basically an associative initiative led by the Chamber of Commerce of Bucaramanga, which has the support of some links in the value chain of the health sector in the region, such as clinics, hospitals, foundations, medical institutes specialized centers, health centers, diagnostic centers, suppliers of specialized equipment, laboratories, universities, and city halls.

Santander's Health Cluster is focused on encouraging professionals to specialize in order to offer highly qualified personnel in each medical category based on an alliance between the main companies in the health sector and academia.

The Santander Health Cluster is still an incipient figure and far from being a functional reality, given the absence of relationships between all the links of the health sector chain, so it does not comply with the basic characteristics that an organism of these proportions demand at the level of identity, associativity, complementarity and competition.

The facilitators of medical tourism are a viable and forceful alternative for the international promotion of Bucaramanga and its metropolitan area, under penalty of its relevance as articulating entities between the links of the health sector value chain and the value chain of tourism in the region.

\section{References}

Adams, K.; Snyder, V.; A Crooks J., \& R. Johnston (2013). Promoting social responsibility amongst health care users: medical tourists' perspectives on an information sheet regarding ethical concerns in medical tourism. Philosophy, Ethics, and Humanities in Medicine. Vol. 8, (19)

Anido, Naïde (2012). The Emergent Medical Tourism: Advantages and Disadvantages of the Medical Treatments Abroad. International Business Research. Vol. 5, (2), pp. 41-50.

Arias-Aragones, F. J., Caraballo-Payares, A. M., \& R.E. Matos-Navas (2012). El turismo de salud: conceptualización, historia, desarrollo y estado actual del mercado global. Clío America. Vol. 6, (11), pp. 72-98.

Branco, Bonfada Patricia, Bonfada Marcel Rodrigo Henn, Gonzalez Maria Elisa Alen, y Gandara Jose Manoel Goncalves. «El turismo de salud y el uso terapéutico del agua.» Estudios y perspectivas en turismo (SciElo) 20, no 2 (Febrero-Abril 2011).

Castro Quesada, R. (2007). Elementos del turismo. Universidad Estatal a Distancia (EUNED). San José, Costa Rica.

CCB, Cámara de Comercio de Bucaramanga $\left(2017^{\mathrm{a}}\right)$. ¿Porque salud? Santander: Informe cluster salud. Informe Clúster Salud, Santander, Bucaramanga: Observatorio de Competitividad.

CCB, Cámara de Comercio de Bucaramanga $\left(2017^{\text {b}}\right)$. iniciativa Clúster de la Salud. Informe Clúster Salud, Santander, Bucaramanga: Observatorio de Competitividad. 
CCB, Cámara de Comercio de Bucaramanga, y Sistema de Información Turística de Santander SITUR. «Turismo en Santander Indicadores diciembre 2018.» Cámara de Comercio de Bucaramanga. 01 de 2019. https://www.camaradirecta.com/temas/documentos\%20pdf/turismo/Turismo_diciembre_2018.pdf (último acceso: 21 de 05 de 2019).

CEPAL, Comisión Económica para América Latina y el Caribe. Medical tourism: a survey. Washingtong, D.C.: United Nations Publication, 2010.

CPTUR, (2017). Centro de Pensamiento Turistico. Índice de Competitividad Turística Regional de Colombia: ICTRC 2017. Bogotá: Cotelco.

De la Puente Pacheco, M. (2015). Dinámica del Turismo de Salud Internacional: una aproximación cuantitativa. Dirección Empresarial. Vol. 13 (2), pp. 167-184

De la Puente, M. (2018). Systematic Competitiveness in Colombian Medical Tourism: An Examination. En Mobilities, Tourism and Travel Behavior - Contexts and Boundaries, pp. 125-142. Barranquilla, Colombia

DPN (2015). Plan Nacional De Desarollo 2014-2018: Todos Por Un Nuevo Pais Paz, Equidad y Educacion (Tomo II). Departamento Nacional de Planeacion.

DNP (2019). Bases del Plan Nacional de Desarrollo 2018 - 2022. Departamento Nacional de Planeación. Recuperado de: https://colaboracion.dnp.gov.co/CDT/Prensa/BasesPND2018-2022n.pdf

FENALCO, y Alcaldía de Medellín (2018). Anuario 2018. Sistema de Indicadores Turísticos de Medellín. Recuperado de: http://situr.gov.co/upload/publications/documents/20190403140455000000Anuario\%202018\%20FINAL.p df

Fuentes, P. (2009). El turismo de salud como producto turistico en auge: Analisis del caso de la Provincia de Buenos Aires. Universidad Nacional de Mar del Plata. Recuperado de: http://nulan.mdp.edu.ar/1388/1/fuentes_p.pdf

Fundación Cardiovascular (2017). Mega Hospital Internacional de Colombia. Recuperado de: https://www.fcv.org/site/acerca-de-la-fcv/filosofia-corporativa/mega

Heung, V.; Kecukusta, D., y H. Song (2011). Medical tourism development in Hong Kong: An assessment of the barriers. Tourism Managment. Vol. 32 (5), pp. 995-1005.

Mendoza, C. (2014). Iniciativa de Ley General de Turismo Médico. Senado de la República (México). Recuperado de: https://infosen.senado.gob.mx/sgsp/gaceta/62/3/2014-11-251/assets/documentos/Ini_FINAL_Turismo_Medico.pdf

MinCIT (2018). Plan Sectorial de Turismo 2018 -2022 Turismo: el propósito que nos une. Ministerio de Comercio Industria y Turismo. Recuperado de: http://www.mincit.gov.co/CMSPages/GetFile.aspx?guid=2ca4ebd7-1acd-44f9-9978-4c826bab5013

Minseong, K.; Dong-Woo, K.; Dong-Jin, S., \& and L. Sae-Mi (2017). From Servicescape to Loyalty in the inquiry. INQUIRY: The Journal of Health Care Organization, Provision, and Financing. Vol. 54, pp. 1-16.

NaRanong, A., y V. NaRanong (2011). The effects of medical tourism: Thailand's experience. Bull World Health Organ. Vol. 89 (5), pp. 336-334

Castro, Quesada Renato. ELEMENTOS DEL TURISMO. San Jose,Costa Rica: Universidad Estatal a Distancia, 2007. 
Quintela, J,; Costa, C., y A. Correia (2016). Health, wellness and medical tourism - A conceptual approach. Enlightening Tourism A Pathmaking Journal. Vol. 6 (1), pp. 1-18

Rey, Bueno Mar. Historia de las hierbas mágicas y medicinales. Editado por Santos Rodriguez. Vol. 44.3 vols. Madrid: Nowtilus S.L, 2008.

Rodríguez Sánchez, J. A. (1998). La supresión del Cuerpo de Médicos de Baños (1932-1936). En J. Castellanos Guerrero (coord.), La medicina en el siglo XX. Estudios Históricos sobre Medicina, Sociedad y Estado (269280). Málaga: Sociedad Española de Historia de la Medicina.

UNWTO, The World Tourism Organization. International Hanbook on Tourism and Peace. Celovec, Austria: Drava, 2014.

UNWTO, The World Tourism Organization. Panorama OMT del turismo internacional. Madrid: UNWTO, 2018.

Turner, L. (2011). Canadian medical tourism companies that have exited the marketplace: Content analysis of websites used to market transnational medical travel. Globalization and Health. BMC: Springer Nature Vol. 7, (40) 